\title{
PENGARUH BERBAGAI JENIS STERILAN DAN WAKTU PERENDAMAN TERHADAP KEBERHASILAN STERILISASI EKSPLAN DAUN KENCUR (Kaempferia galanga L) PADA TEKNIK KULTUR IN VITRO
}

\author{
Anis Shofiyani, Agus Mulyadi Purnawanto, Reza Zahara Abdul Aziz, \\ Program Studi Agroteknologi, Fakultas Pertanian \\ Universitas Muhammadiyah Purwokerto \\ Email: shofiyanianis@gmail.com
}

\begin{abstract}
This study aims to determine the effect of sterile and immersion duration on the success of sterilization of kencur (Kaempferia galanga L) leaf explants using in vitro culture techniques and to find out the types of contaminants that emerge. The study was conducted from October 2018 to February 2019, located at the Basic Agrotechnology Laboratory and Plant Engineering Laboratory, Faculty of Agriculture, Universitas Muhammadiyah Purwokerto. The design used was a randomized block design (RBD) with 15 treatments. Each treatment was repeated 3 times. The treatments were the immersed in 6\% chlorine for 10 minutes (S1), for 15 minutes (S2), for 20 minutes (S3), the immersed in $0,1 \mathrm{~g} / \mathrm{ml} \mathrm{HgCl} 2$ for 1 minute (S4), for 3 minutes (S5), for 5 minutes (S6), the immersed in $\mathrm{HgCl} 20,2 \mathrm{~g} / \mathrm{ml}$ for 1 minute (S7), for 3 minutes (S8), for 5 minutes (S9), the immersed in $\mathrm{HgCl2} \mathrm{0,3}$ $\mathrm{g} / \mathrm{ml}$ for 1 minute (S10), for 3 minutes (S11), 5 minutes (S12), immersed in dithane $2 \mathrm{~g} / \mathrm{l}$ for 1 hour (S13), for 12 hours (S14), for 24 hours (S15). The results showed that the treatment of Dithane sterile $2 \mathrm{~g} / \mathrm{l}$ water with an immersion duration of 1 hour (S13) significantly affected the percentage of contamination and succeeded in reducing contamination by $44.44 \%$, while the use of chlorine sterile and $\mathrm{HgCl} 2$ had no significant effect. The types of contaminants that appear are Macrophomoina sp., Aspergillus sp., Cladosporium sp., And Pseudomonas sp.
\end{abstract}

\section{Keywords : Sterilization, Kencur, Hgcl2, Chlorine, Dithane}

\section{PENDAHULUAN}

Kencur (Kaempferia galanga L.) adalah salah satu tanaman temu-temuan (Zingiberaceae) yang berkhasiat sebagai obat. Kencur telah banyak manfaatkan sebagai bahan baku obat tradisional (jamu), fitofarmaka, industri kosmetika, penyedap rasa makanan dan minuman, rempah-rempah. Penelitian sebelumnya menginformasikan peran kencur sebagai penambah nafsu makan, pengobatan infeksi bakteri, obat batuk, disentri, tonikum, ekspektoran, masuk angin, sakit perut karena rimpangnya mengandung antara lain saponin, flavanoid, fenol serta minyak atsiri (Syamsuhidayat dan Johnny, 1991).

Menurut Rahmat (2004) pada permintaan kencur yang tinggi di Indonesia terutama dari pabrik obat mendorong para petani untuk dapat memenuhi kencur dalam jumlah banyak. Pengembangan tanaman kencur di lapangan pada umumnya menggunakan rimpang hal ini memiliki beberapa kekurangan seperti, rentan terhadap hama dan penyakit, biaya mahal, serta pada produktivitasnya kurang stabil pada musim kemarau (off season). Upaya yang dilakukan saat ini dalam perbanyakan kencur 
adalah dengan metode kultur jaringan tanaman karena mampu menghasilkan rimpang kencur dengan hasil yang tinggi dan seragam, serta dapat memenuhi stok bibit steril sehingga dapat digunakan untuk perbanyakan selanjutnya (Lestari, 2011).

Pengembangan bibit tanaman kencur dengan metode kultur in vitro ternyata memiliki kendala, salah satu kendala yang sering dihadapai adalah sterilisasi eksplan untuk mendapatkan bahan tanam yang steril sehingga kegagalan kegiatan kultur in vitro akibat kontaminasi dapat dihindari. Menurut Sandra (2002), sterilisasi merupakan permasalahan utama yang menentukan keberhasilan kultur jaringan, terutama sterilisasi eksplan yang berasal dari luar atau lapang. Jika sterilisasi gagal maka kegiatan selanjutnya tidak bermanfaat.

Kesulitan perbanyakan tumbuhan yang terkontaminasi mikroorganisme dengan kultur jaringan, yaitu bagaimana menghilangkan mikroorganisme sumber kontaminan dengan bahan sterilian tanpa mematikan tumbuhan (eksplan) (Darmono, 2003). Menurut Gunawan (1987) bahan-bahan sterilisasi yang biasa digunakan umumnya bersifat toksik terhadap jaringan. Melihat hal tersebut konsentrasi sterilan harus diperhatikan agar bisa menghilangkan kontaminan tetapi tidak merusak atau mematikan eksplan.

Berbagai cara sterilisasi telah banyak dilakukan oleh peneliti maupun pelaksana kultur in vitro dengan menggunakan berbagai macam cara yang diharapkan efektif untuk menghilangkan sumber kontaminan yang terdapat dalam eksplan. Kombinasi bahan sterilan dan waktu perendaman yang tepat merupakan salah satu faktor yang menentukan keberhasilan streilisasi. Ada berbagai bahan kimia sterilant yang dibutuhkan untuk sterilisasi eksplan yaitu natrium hipoklorit $(\mathrm{NaClO})$, Sodium hipoklorit (klorox), merkuri khlorit (Sublimat), detergent dan alkohol 70\% (Shofiyani dan Hajoeningtijas, 2010). Berdasarkan penelitian sebelumnya pada sterilisasi daun tanaman kemiri dengan perlakuan $\mathrm{NaClO} 1 \%$ dengan lama perendaman 2,5 menit terbukti mampu menurunkan kontaminasi hingga $0 \%$ (Lutfiyani, 2018). Fauzan et al.(2017) menyatakan pada penelitiannya perlakuan $\mathrm{HgCl} 2300$ mg/L merupakan konsentrasi terbaik untuk sterilisasi kultur tunas samping jati yang dapat menghasilkan kultur dengan tingkat aseptik tertinggi yaitu sebanyak $85 \%$. Menurut Suratman et al. (2013) Pemberian bahan sterilisasi $\mathrm{NaClO} 3 \%$ selama 5 menit yang dikombinasikan dengan $\mathrm{HgCl} 2 \quad 0,1 \%$ selama 5 menit memberikan hasil yang terbaik dalam menekan persentase terkontaminasi pada eksplan daun.

\section{METODE PENELITIAN}

\section{Bahan dan Alat}

Alat yang digunakan antara lain : Laminar air flow cabinet (HALF-250), Autoclav (All American 1925X 25Qt 24L), Hot plate magnetic stirer (Favorit HS0707V2), jarum ose, gelas objek, mikroskop (nikon, jepang),

Bahan : daun tanaman kencur varietas 
Galesia 2, agar, sukrosa, fungisida Dithane, $\mathrm{HgCl}$, larutan alkohol 70\%, larutan kaporit, aquades, crystal violet, lugol, safranin, media $\mathrm{MS}$, zat pengatur tumbuh (2,4D) 2,4 Diklorofenoksiasetat dan (BA) Benzil Adenin.

\section{Persiapan dan Sterilisasi Eksplan}

Eksplan berupa daun tanaman kencur varietas Galesia 2 yang diperoleh dari BALITRO, Bogor. Daun kedua dijadikan bahan eksplan dalam penelitian ini. Daun kencur yang sudah terpilih dipotong dengan ukuran 0,5 x 0,5 cm, dan untuk menghilangkan kotoran yang terdapat pada masing-masing eksplan dilakukan pencucian menggunakan air mengalir dan deterjen sampai bersih kemudian melanjutkan dengan sterilisasi sesuai perlakuan.

\section{Penanaman Eksplan dan pemeliharaan}

Eksplan yang telah melalui proses sterilisasi sesuai perlakuan selanjutnya ditanam dalam media dasar MS dengan penambahan 2,4 D 2 ppm dan BA 0,5 ppm. Penanaman dilakukan di dalam Laminar Air Flow (LAF) untuk mendapatkan kondisi lingkungan steril pada saat penanaman eksplan yang bertujuan untuk menghindari adanya kontaminasi dari jamur ataupun bakteri.

Pemeliharaan dilakukan untuk menghindari kontaminasi yang disebabkan oleh lingkungan sekitar kultur yang kurang steril dengan melakukan penyemprotan dengan alkohol $70 \%$ pada botol-botol kultur yang berisi eksplan..

\section{Rancangan percobaan}

Penelitian ini menggunakan Rancangan Acak Kelompok (RAK) dengan 15 perlakuan.
Pada masing-masing perlakuan terdapat 3 ulangan dengan 3 sampel pada masing-masing ulangan sehingga digunakan 135 botol eksplan. Sterilisasi yang dilakukan menggunakan 3 (tiga) metode sebagai berikut: Metode I

Metode ini menggunakan bahan sterilan berupa larutan kaporit $\left(\mathrm{CaClO}_{2}\right)$ dengan konsentrasi $6 \%$ yang terdiri atas 3 perlakuan lama perendaman, yaitu dengan waktu lama perendaman 10 menit, 15 menit, dan 20 menit serta dikombinasikan dengan larutan alkohol $70 \%$ selama 2 menit.

\section{Metode II}

Menggunakan sterilan berupa larutan $\mathrm{HgCl} 2$ (Mercuri) dengan konsentrasi $0,1 \mathrm{~g} / \mathrm{ml} ; 0,2$ $\mathrm{g} / \mathrm{ml}$; dan $0,3 \mathrm{~g} / \mathrm{ml}$ yang dikombinasikan dengan lama perendaman 1 menit, 3 menit, dan 5 menit.

\section{Metode III}

Menggunakan larutan Dithane dengan konsentrasi 2 g/l dan lama waktu perendaman selama 1 jam, 12 jam, dan 24 jam serta dikombinasikan dengan alkohol $70 \%$ selama 2 menit.

Berdasarkan ketiga metode sterilisasi diatas maka kombinasi perlakuan meliputi : perendaman dalam kaporit 6\% selama 10 menit (S1), 15 menit (S2), 20 menit (S3), direndam dalam $\mathrm{HgCl} 20,1 \mathrm{~g} / \mathrm{ml}$ selama 1 menit (S4), selama 3 menit (S5), selama 5 menit (S6), $\mathrm{HgCl} 2$ 0,2 g/ml selama 1 menit (S7), selama 3 menit (S8), selama 5 menit (S9), $\mathrm{HgCl} 20,3$ $\mathrm{g} / \mathrm{ml}$ selama 1 menit (S10), selama 3 menit (S11), 5 menit (S12), direndam dalam dithane 2 g/l selama 1 jam (S13), selama 12 jam (S14), 
selama 24 jam (S15). Variabel yang diamati pada penelitian ini yaitu, persentase kontaminasi, waktu pertama kontaminasi, sumber kontaminasi, dan identifikasi sumber kontaminan.

\section{Pengamatan dan Analisis data}

Variabel pengamatan meliputi persentase kontaminasi, waktu pertama kontaminasi, sumber kontaminasi, dan identifikasi sumber kontaminan. Data yang diperoleh dari hasil penelitian berupa data kualitatif dan kuantitatif. Data kualitatif seperti sumber kontaminasi dan identifikasi kontaminasi. Data kuantitatif meliputi persentase kontaminasi dan waktu pertama kontaminasi, dianalisis secara statistik menggunakan aplikasi SPPS versi 25. Data dianalisis menggunakan analisis variansi (ANOVA), apabila terdapat perbedaan yang nyata maka akan dilanjutkan dengan DMRT pada taraf $5 \%$.

\section{HASIL DAN PEMBAHASAN}

\section{Hasil Pengamatan}

Hasil penelitian menunjukkan bahwa masing-masing metode sterilisasi menunjukkan hasil yang berbeda terhadap penekanan tingkat kontaminasi yang terjadi pada eksplan. Ketiga metode yang diujikan menunjukkan hasil untuk perlakuan sterilan berupa larutan kaporit $(\mathrm{CaClO} 2)$ dengan konsentrasi $6 \%$ yang terbagi atas 3 lama perendaman, yaitu dengan waktu 10 menit, 15 menit, dan 20 menit serta dikombinasikan dengan larutan alkohol $70 \%$ selama 2 menit. Penggunaan metode ini tingkat kontaminasi masih $100 \%$ dengan sumber kontaminan yang berasal dari jamur, yang ditandai dengan adanya hifa atau benang miselium.

Metode sterilisasi eksplan daun kencur menggunakan bahan sterilan berupa larutan $\mathrm{HgCl} 2$ (Mercuri) dengan konsentrasi 0,1 g/ml; $0,2 \mathrm{~g} / \mathrm{ml}$; dan $0,3 \mathrm{~g} / \mathrm{ml}$ yang dikombinasikan dengan lama perendaman 1 menit, 3 menit, dan 5 menit. Penggunaan metode ini menunjukkan hasil tingkat pesentase kontaminasi masih tinggi berkisar antara $66,66 \%$ sampai $100 \%$, dengan sumber kontaminan yang berasal dari jamur yang ditandai dengan adanya hifa atau benang miselium dan bakteri yang ditandai dengan bercak-bercak lendir pada permukaan media.

Metode dengan menggunakan larutan Dithane dengan konsentrasi $2 \mathrm{~g} / 1$ dengan lama perendaman masing-masing selama 1 jam, 12 jam, dan 24 jam serta dikombinasikan dengan alkohol $70 \%$ selama 2 menit. Penggunaan metode ini didapatkan hasil yang lebih baik jika dibandingkan dengan metode I dan II, karena mampu menekan persentase kontaminasi hingga $0 \%$ atau tidak ada kontaminasi baik itu jamur maupun bakteri. Efektifitas penggunaan metode sterilisasi dalam penelitian yang dilaksanakan disajikan dalam tabel 1.

\section{Persentase Kontaminasi}

Berdasarkan hasil analisis sidik ragam pada Tabel 1 untuk perlakuan S1, S2, S3, S4, S5, S6, S7, S9, S10, S11, dan S12, dengan jenis sterilan kaporit dan $\mathrm{HgCl} 2$ tidak berbeda nyata, sedangkan perlakuan S14 dan S15 tidak mengalami kontaminasi. Pada perlakuan S13 dengan jenis sterilan Dithane berbeda nyata 
terhadap persentase kontaminasi. Tingkat kontaminasi pada perlakuan yaitu sebesar $66,66 \%-100,00 \%$ hal tersebut diduga karena lama perendaman yang relatif singkat dan tingkat konsentrasi jenis sterilan kaporit dan $\mathrm{HgCl} 2$ yang rendah sehingga sterilan kurang meresap dan dapat mengendalikan kontaminasi pada eksplan daun. Sejalan hasil penelitian Farooq et al., (2002) Senyawa kaporit yang diberikan dalam konsentrasi rendah dan lama perendaman singkat tidak terlalu efektif dalam mengendalikan kontaminasi pada eksplan. Peran kaporit terhadap penekanan tingkat kontaminan yaitu dengan cara melepaskan ion klorin yang mampu membunuh mikroorganisme dengan cara mengoksidasi sel membran sehingga akan merusak sel mikroorganisme tersebut (Estrela, 2002).

Penggunaan $\mathrm{HgCl}_{2}$ dalam sterilisasi eksplan sering dilakukan karena merupakan jenis sterilan yang mengandung ion merkuri yang dapat menyebabkan toksik karena terjadi proses presipitasi protein yang dapat menghambat aktifitas enzim dan bersifat sangat korosif. Pengaruh $\mathrm{HgCl}_{2}$ terhadap penekanan kontaminan, yaitu dengan melepaskan ion $\mathrm{Hg} 2+$ yang dapat menyebabkan pengaruh toksik pada proses presipitasi protein sehingga menghambat aktivitas enzim yang akan bertindak sebagai bahan yang bersifat korosif (Alfian, 2006). Sedangkan Penelitian dari Priadi (2008) menyatakan penggunaan $\mathrm{HgCl}_{2}$ dengan konsentrasi rendah dan lama perendaman singkat belum mampu menekan persentase kontaminasi pada tunas ubi kayu, ditunjukkan dengan persentase kontaminasi pada genotip Iding mencapai 30-70\% dan pada genotip Gebang mencapai 20-60\%.

Pada perlakuan S13, dengan jenis sterilan Dithane berbeda nyata terhadap persentase kontaminasi, ditunjukkan dengan persentase kontaminasi yang mampu menekan dibawah $50 \%$ yaitu $44,44 \%$. Sejalan dengan penelitian sebelumnya yang menunjukkan bahwa perendaman menggunakan larutan Dithane selama 24 jam dilanjutkan dengan perendaman bakterisida, dan perendaman pada alkohol $70 \%$ selama 1 menit mampu dengan optimal mengendalian kontaminasi pada eksplan daun burahol (Habibah et al., 2013). Senyawa Dithane merupakan fungisida yang sering digunakan pada sterilisasi teknik kultur in vitro, karena terdapat senyawa mankozeb dalam Dithane yang dapat mencegah infeksi jamur dengan menghambat perkecambahan spora yang menempel dipermukaan tanaman (Djojosumarto, 2004).

Penyebab kontaminasi dapat bersumber dari media maupun eksplan yang kurang sempurna dalam sterilisasi sehingga tumbuh bakteri atau jamur pada eksplan maupun media kultur. Kontaminasi pada media dan eksplan juga dapat terjadi karena adanya jamur ataupun bakteri yang tidak mati saat sterilisasi media maupun yang masuk dalam media saat proses penanaman eksplan atau saat pemeliharaan. 
Tabel 1. Pengaruh Metode Sterilisasi pada Eksplan Daun Tanaman Kencur terhadap Kontaminasi Eksplan.

\begin{tabular}{|c|c|c|c|}
\hline Perlakuan & $\begin{array}{l}\text { Persentase } \\
\text { kontaminasi } \\
(\%)\end{array}$ & $\begin{array}{l}\text { Waktu } \\
\text { pertama } \\
\text { kontaminasi } \\
\text { (hst) }\end{array}$ & $\begin{array}{l}\text { Identifikasi } \\
\text { kontaminan }\end{array}$ \\
\hline $\mathrm{S} 1$ & $100,00 \mathrm{~d}$ & $4,55 \mathrm{c}$ & Macrophomoina sp. \\
\hline $\mathrm{S} 2$ & $100,00 \mathrm{~d}$ & $4,66 \mathrm{c}$ & Aspergillus sp. \\
\hline S3 & $100,00 \mathrm{~d}$ & $4,55 \mathrm{c}$ & Aspergillus sp. \\
\hline $\mathrm{S} 4$ & $100,00 \mathrm{~d}$ & $4,44 \mathrm{c}$ & Aspergillus sp. \\
\hline S5 & $100,00 \mathrm{~d}$ & $4,44 \mathrm{c}$ & Aspergillus sp. \\
\hline S6 & $88,88 \mathrm{~cd}$ & $3,99 b c$ & Aspergillus sp. \\
\hline S7 & $100,00 \mathrm{~d}$ & $4,55 \mathrm{c}$ & Aspergillus sp. \\
\hline S8 & $66,66 \mathrm{bc}$ & $3,10 b c$ & Aspergillus sp. \\
\hline S9 & $88,88 \mathrm{~cd}$ & $3,99 b c$ & $\begin{array}{l}\text { Aspergillus sp. dan } \\
\text { Pseudomonas sp. }\end{array}$ \\
\hline S10 & $100,00 \mathrm{~d}$ & $4,44 \mathrm{c}$ & Cladosporium sp. \\
\hline $\mathrm{S} 11$ & $88,88 \mathrm{~cd}$ & $4,44 \mathrm{c}$ & Aspergillus sp. \\
\hline $\mathrm{S} 12$ & $77,77 \mathrm{~cd}$ & $3,88 \mathrm{bc}$ & Cladosporium sp. \\
\hline S13 & $44,44 b$ & $2,44 b$ & Cladosporium sp. \\
\hline S14 & $0,00 \mathrm{a}$ & $0,00 \mathrm{a}$ & - \\
\hline S15 & $0,00 \mathrm{a}$ & $0,00 \mathrm{a}$ & - \\
\hline
\end{tabular}

Keterangan : Angka yang diikuti huruf yang sama pada kolom yang sama menunjukkan tidak berbeda nyata pada taraf 5\% menurut DMRT. S1 = kaporit 6\% selama 10 menit; S2 = kaporit 6\% selama 15 menit; S3 = kaporit 6\% selama 20 menit; $\mathrm{S} 4=\mathrm{HgCl} 20,1 \mathrm{~g} / \mathrm{ml}$ selama 1 menit; $\mathrm{S} 5=\mathrm{HgCl} 20,1 \mathrm{~g} / \mathrm{ml}$ selama 3 menit; $\mathrm{S} 6=\mathrm{HgCl} 20,1 \mathrm{~g} / \mathrm{ml}$ selama 5 menit; $\mathrm{S} 7=\mathrm{HgCl} 2$ 0,2 g/ml selama 1 menit; $\mathrm{S} 8=\mathrm{HgCl} 20,2 \mathrm{~g} / \mathrm{ml}$ selama 3 menit; $\mathrm{S} 9=\mathrm{HgCl} 20,2 \mathrm{~g} / \mathrm{ml}$ selama 5 menit; $\mathrm{S} 10=\mathrm{HgCl} 20,3 \mathrm{~g} / \mathrm{ml}$ selama 1 menit; $\mathrm{S} 11=\mathrm{HgCl} 20,3 \mathrm{~g} / \mathrm{ml}$ selama 3 menit; $\mathrm{S} 12=\mathrm{HgCl} 2$ 0,3 g/ml selama 5 menit; $\mathrm{S} 13$ = dithane $2 \mathrm{~g} / \mathrm{lg} / \mathrm{ml}$ selama $1 \mathrm{jam} ; \mathrm{S} 14$ = dithane $2 \mathrm{~g} / \mathrm{lg} / \mathrm{ml}$ selama $12 \mathrm{jam} ; \mathrm{S} 15$ = dithane $2 \mathrm{~g} / \mathrm{l} \mathrm{g} / \mathrm{ml}$ selama $24 \mathrm{jam}$.

Kontaminasi yang disebabkan oleh bakteri awalnya ditandai dengan pembentukan selaput bening yang membayang pada media dan berubah menjadi putih kekuningan. Jamur yang muncul awalnya berupa kumpulan spora berwarna putih maupun coklat pada media atau eksplan yang kemudian menyebar disekeliling media dan menutupi seluruh permukaan eksplan, hingga akhirnya eksplan tersebut mati (Hidayat, 2005).

\section{Waktu Pertama Kontaminasi}

Berdasarkan hasil analisis sidik ragam padan Tabel 1 untuk semua perlakuan tidak berbeda nyata. Rata-rata waktu pertama kontaminasi muncul yaitu 2,44 - 4,66 hst, sedangkan pada perlakuan S14 dan S15 tidak mengalami kontaminasi. Perbedaaan waktu pertama terjadi kontaminasi diduga terkait dengan jenis kontaminasi eksternal. Penelitian dari Pancaningtyas dan Cahya (2006) menyatakan bahwa kontaminasi eksternal umumnya muncul setelah beberapa hari hingga 1 bulan setelah tanam. Penyebab kontaminasi pada teknik kultur jaringan tanaman dapat berasal dari eksplan, organisme kecil yang masuk ke dalam media, botol kultur atau alat-alat tanam yang kurang steril, lingkungan kerja dan ruang kultur 
yang kotor serta kecerobohan dalam pelaksanaan (Gunawan, 1992).

\section{Sumber Kontaminasi}

Pengamatan terhadap sumber kontaminasi pada penelitian ini menunjukkan bahwa sumber kontaminasi disebabkan oleh jamur maupun bakteri. Berdasarkan Tabel 1 dapat dilihat kontaminan yang bersumber dari jamur menyerang beberapa perlakuan yang diteliti dengan hasil yang beragam untuk sumber kontaminan yang menyerang.

Kontaminan berupa jamur pada eksplan daun diduga karena daun mengalami kontak langsung dengan udara yang banyak mengandung spora jamur. Mendominasinya cendawan yang hidup dalam botol kultur mengakibatkan eksplan yang ditanam tidak memiliki ruang untuk tumbuh yang cukup sehingga menghambat pertumbuhannya dan akhirnya berakhir pada kematian ekplan itu sendiri. Jamur atau cendawan pada umumnya berbentuk seperti benang halus yang tidak bisa dilihat dengan mata telanjang. Namun, kumpulan dari benang halus ini yang disebut miselium bisa dilihat dengan jelas. Jamur memiliki warna miselium yang bermacammacam, yaitu berwarna putih, coklat, hitam, merah dan lain sebagainya (Wudianto,2002). Kontaminan pada penelitian ini tidak hanya bersumber dari jamur tetapi juga bakteri. Kontaminasi yang sering dijumpai pada kultur in vitro adalah Agrobacterium, Bacillus, Corynebacterium, Enterobacter, Lactobacillus, Pseudomonas, Staphylococcus, dan
Xanthomonas (Wolf, 2007). Tabel 1 menunjukkan perlakuan $\mathrm{S} 9(\mathrm{HgCl} 2 \mathrm{~g} / \mathrm{ml}$ selama 5 menit) mengalami kontaminasi bakteri. Sumber kontaminasi yang disebabkan oleh bakteri menunjukkan ciri-ciri terbentuknya lapisan lendir berwarna putih dan lendir berwarna putih kecoklatan di bagian permukaan media yang terkontaminasi. Selain itu, faktor lain yang mendukung terjadinya kontaminasi seperti bahan sterilan yang kurang meresap pada eksplan sehingga masih terdapat mikroorganisme penyebab kontaminasi dan faktor lingkungan yang kurang steril (Tulainy,2016).

\section{Identifikasi Kontaminasi}

Karakteristik mikromorfologis jenis jamur pada Tabel 2 untuk gambar A, yaitu memiliki konidiofor bersekat, bercabang, berwarna abuabu kehitaman, memiliki bagian berbentuk lonjong, berwarna hitam (Sklerotia) dan tidak ada konidia, diduga jenis jamur ini adalah jamur Macrophomoina sp. Menurut Watanabe (2002) pada jamur jenis Macrophomoina sp. memiliki karakteristik mikromorfologis memiliki hifa yang bersekat, konidiafor hialin, memiliki sklerotia dengan bentuk bulat lonjong dan berwarna hitam, selalu terbentuk dalam satu gerombolan dan jarang atau tidak terdapat pycnidia.

Karakteristik mikromorfologis jenis jamur pada Tabel 2 untuk gambar B, yaitu memiliki konidiofor berbentuk tegak lurus sederhana tidak bercabang dan tidak bersekat, diujung konidiofor terdapat konidia berbentuk bulat 
berwarna abu-abu kehitaman, diduga jenis jamur ini adalah jamur Aspergillus sp. Menurut Samson et al. (1988) pada gambaran jamur Aspergillus sp. terdiri atas kepala konidia, konidia, fialid, vesikel dan konidiofor. Kepala konidia adalah struktur yang terletak di bagian terminal konidiofor, berbentuk bulat (globose) atau semi bulat (subglobose) tersusun atas vesikel, metula (jika ada), fialid dan konidia. Vesikel merupakan pembesaran konidiofor pada bagian apeksnya membentuk suatu struktur berbentuk globose, hemisferis, elips atau clavate. Konidiofor merupakan suatu struktur tegak lurus yang muncul dari sel kaki dan pada ujungnya menghasilkan kepala konidia. Sebagian besar dari spesies Aspergillus sp. memiliki konidiofor tidak bercabang yang masing-masing menghasilkan kepala konidia tunggal (Samson et al. 1988).

Tabel 2. Karakteristik mikromorfologis jenis jamur yang mengontaminasi eksplan daun tanaman kencur.

\begin{tabular}{|c|c|c|c|}
\hline No. & Perlakuan & Bentuk konidium & $\begin{array}{l}\text { Diduga Jenis } \\
\text { jamur }\end{array}$ \\
\hline 1 & $\mathrm{~S} 1$ & $\begin{array}{l}\text { konidiofor bersekat, bercabang } \\
\text { dan berwarna abu-abu } \\
\text { kehitaman; memiliki bagian } \\
\text { berbentuk lonjong dan berwarna } \\
\text { hitam (Sklerotia); tidak ada } \\
\text { konidia. }\end{array}$ & Macrophomoina sp. \\
\hline 2 & $\begin{array}{l}\text { S2, S3, S4, S5, S6, S7, } \\
\text { S8, S9 dan S11 }\end{array}$ & $\begin{array}{l}\text { konidiofor berbentuk tegak lurus } \\
\text { sederhana tidak bercabang dan } \\
\text { tidak bersekat, diujung } \\
\text { konidiofor terdapat konidia } \\
\text { berbentuk bulat berwarna abu- } \\
\text { abu kehitaman. }\end{array}$ & Aspergillus sp. \\
\hline 3 & S10, S12, dan S13 & $\begin{array}{l}\text { konidiofor becabang, tidak } \\
\text { bersekat dan berwarna } \\
\text { transparan; konidia terdapat di } \\
\text { bagian konidiofor menempel } \\
\text { seperti rangkaian. }\end{array}$ & Cladosporium sp. \\
\hline
\end{tabular}

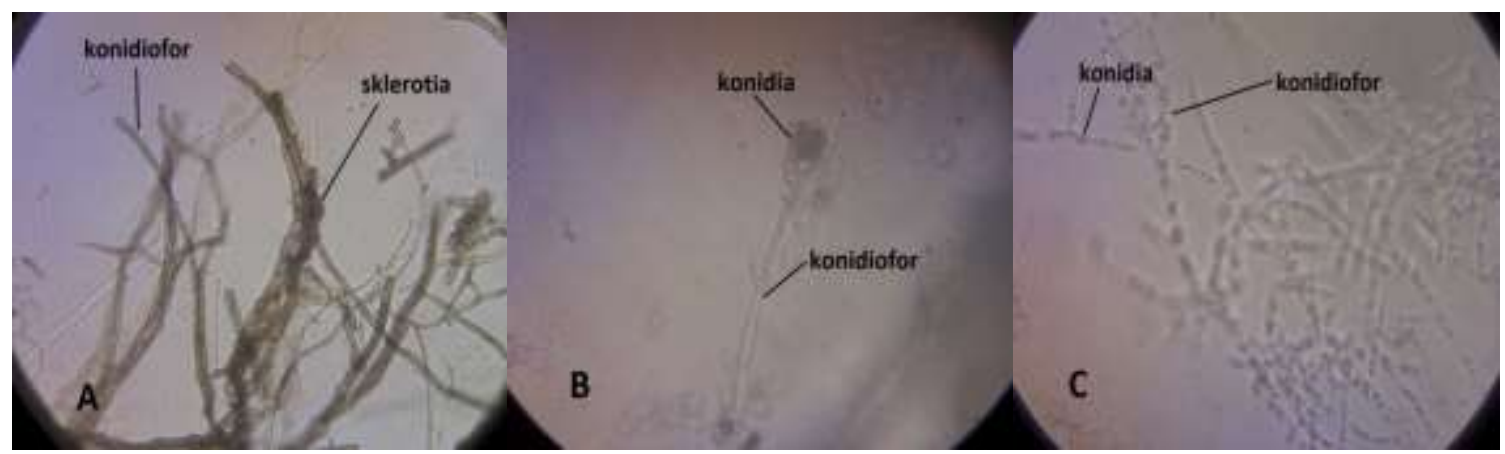

Gambar 1. Diduga jenis jamur yang muncul pada perlakuan metode sterilisasi eksplan daun kencur A. Macrophomoina sp. pada perlakuan kaporit 6\% selama 10 menit; B. Aspergillus sp. pada perlakuan $\mathrm{HgCl} 2$ 0,1 selama 1 menit; C. Cladosporium sp. pada perlakuan $\mathrm{HgCl} 2$ 0,3 selama 1 menit, (dengan perbesaran 10x100). 
Karakteristik mikromorfologis jenis jamur pada Tabel 2 untuk gambar $\mathrm{C}$, yaitu memiliki konidiofor becabang, tidak bersekat, berwarna transparan, konidia terdapat di bagian konidiofor menempel seperti rangkaian. Diduga jenis jamur ini adalah jamur Cladosporium sp. Menurut Crous et al. (2005) pada jamur Cladosporium sp. memiliki konidiofor yang berpigmen transparan bercabang serta pada konidia menempel seperti di dalam rangkaian konidiofor.

Morfologi koloni bakteri yang mengkontaminasi eksplan dalam penelitian ini tersaji pada tabel 3

Tabel 3. Morfologi koloni bakteri yang mengontaminasi eksplan daun tanaman kencur.

\begin{tabular}{lllll}
\hline perlakuan & Bentuk atas & Bentuk pinggir & Bentuk permukaan & Warna koloni \\
\hline S9 & Bulat & Bergelombang & Datar & Putih susu \\
\hline
\end{tabular}

Berdasarkan Tabel 3, morfologi koloni dari bakteri yang mengontaminasi pada perlakuan S9 memiliki penampakan bentuk atas bulat dengan bentuk pinggiran bergelombang serta bentuk permukaan datar dan warna koloni putih. Bentuk koloni dari suatu bakteri dipengaruhi oleh umur dan syarat pertumbuhan tertentu (Hidayat et al., 2006). Variasi bentuk bakteri yang terjadi juga dipengaruhi oleh lingkungan (faktor-faktor biotik dan abiotik), $\mathrm{pH}$, faktor makanan atau medium tumbuh dan suhu minimum, optimum, dan maksimum (Ilyas, 2001). Koloni bakteri yang berwarna coklat, kuning, putih, putih susu, dan, kuning muda. Perbedaan warna pada setiap koloni disebabkan oleh adanya pigmen yang dihasilkan oleh bakteri. Menurut Savitri (2006) menyatakan bahwa pigmen karotenoid, antosianin, melanin, tripirilmetin, dan penazin, masing-masing dari pigmen tersebut akan memberikan warna yang berbeda-beda.

Tabel 4. Hasil pewarnaan gram dan bentuk sel bakteri yang mengontaminasi eksplan daun tanaman kencur.

\begin{tabular}{llc}
\hline Perlakuan & Bentuk sel & \multicolumn{2}{c}{ Pewarnaan } \\
\hline S9 & Coccus (bulat) & Negatif \\
\hline
\end{tabular}

Gambar 3. Bakteri spesies Pseudomonas sp. yang tumbuh pada perlakuan $\mathrm{S} 9$ ( $\mathrm{HgCl} 2$ 0,2 g/ml selama 5 menit) dengan perbesaran $10 \times 100$. 
Pada Tabel 4. hasil dari pewarnaan gram yaitu negatif dengan ciri-ciri berwarna merah atau merah muda. Bakteri gram negatif mengandung lipid, lemak atau substansi, seperti lemak dalam persentase lebih tinggi daripada yang dikandung bakteri gram positif, selain itu peptidoglikan bakteri gram negatif juga lebih tipis daripada peptidoglikan bakteri gram positif (Hadioetomo et al., 2005)

Berdasarkan dari hasil pada Tabel 3 dan Tabel 4 diduga bakteri tersebut adalah jenis bakteri Pseudomonas sp. Menurut Holt et al. (1994) bahwa pada bakteri Pseudomonas sp. bersifat gram negatif, bentuk sel coccus (bulat), motil, tidak berspora, warna koloni putih susu, bersifat aerob, katalase positif, oksidase positif, tidak mampu memfermentasi tetapi dapat mengoksidasi glukosa/karbohidrat lain, tidak mempunyai selubung (sheat) dan mempunyai flagel monotrika (flagel tunggal pada kutub) sehingga selalu bergerak.

\section{Kesimpulan}

Penggunaan sterilan Dithane $2 \mathrm{~g} / \mathrm{l}$ air dengan lama perendaman 1 jam pada perlakuan S13 berbeda nyata dan berhasil menurunkan kontaminasi antara 44,44\%, sedangakan penggunaan sterilan kaporit dan $\mathrm{HgCl}_{2}$ tidak berbeda nyata. Berdasarkan identifikasi kontaminasi terdapat kontaminan berupa jamur dan bakteri, jenis jamur antara lain Macrophomoina sp., Aspergillus sp., dan Cladosporium sp. sedangkan jenis bakteri antara lain Pseudomonas sp.

\section{DAFTAR PUSTAKA}

Adji, Dhirgo. 2007. Perbandingan Efektivitas Sterilisasi Alkohol 70\%, Inframerah, Otoklaf, dan Ozon terhadap Pertumbuhan Bakteri Bacillus subtilis. Jurnal Sain Veteriner. Vol 25, No 1. Hlm. 17-24.

Alfian Z. 2006. Merkuri: Antara Manfaat Dan Efek Penggunaannya Bagi Kesehatan Manusia Dan Lingkungan. Fakultas Matematika dan Ilmu Pengetahuan Alam. Universitas Sumatera Utara, Medan

Crous PW, Schroers H-J, Groenewald JZ, Braun U, Schubert K. 2005. Metulocladosporiella gen. nov. for the casual organism of Cladosporium speckle disease of banana. Mycological Research 110:256-275. DOI :10.1016

Darmono,D.W.2003.Menghasilkan Anggrek Silangan. Jakarta : Penebar Swadaya.

Djojosumarto, P. 2004. Teknik Aplikasi Pestisida Pertanian. Kanisius, Yogyakarta. $211 \mathrm{p}$.

Estrela, C., Barbin E.L., Spano J.C., Marchesan, M.A., 2002. Mechanism of action of sodium Hypochlorite.BrazDentJ.13(2):113-117.

Fauzan, Y.S.A, Supriyanto, Tajuddin T. 2017. Efektivitas Merkuri Klorida $\left(\mathrm{HgCl}_{2}\right)$ Pada Sterilisasi Tunas Samping Jati (Tectona Grandis) In Vitro. J Bioteknol Biosains Indones - Vol 4 No 2 Thn 2017

Farooq SA, Farooq TT, Rao TV (2002) Micropropagation of Annona squamosa L. using nodal explants. Pakistan Journal of Biological Sciences 5(1): 43-46.

Gunawan LW. 1987. Teknik Kultur Jaringan. Lembaga Sumberdaya Informasi IPB. Bogor : Laboratorium Kultur 34 an Tanaman Pusat Antar Uln...utas Bioteknologi IPB

Gunawan LW (1992) Teknik Kultur Jaringan Tanaman. PAU Bioteknologi. Departemen Pendidikan dan Kebudayaan. Direktorat Jenderal Pendidikan Tinggi. Institut Pertanian Bogor, Bogor

Habibah, NA, Sumadi, Ambar S (2013) Optimasi Sterilisasi Permukaan Daun dan 
Eliminasi Endofit pada Burahol. Journal of Biology \& Biology Education Biosaintifika 5 (2) : 95 - 99

Hadioetomo, Katna S., Imas T., Tjitrosono S.S., Angka S.L. 2005. Dasar-Dasar Mikrobiologi 1. UI, Jakarta.

Hidayat N. M.C. Padaga, Suharti S. 2006. Mikrobiologi Industri. Penerbit Andi, Yogyakarta.

Holt, J. G., N. R. Krieg, P. H. A. Sneath, J. T. Staley, S. T. Wiliam. 1994.BergeysManualofDeterminative Bacteriology 9th ed. Lippincott Wiliamand Wikins. Philadelphia. 785 hal

Ilyas, S. 2001. Mikrobiologi Dasar Diklat Kompilasi 28. Universitas Sumatra Utara Press, Medan

Lestari E.G. 2011. Peranan Zat Pengatur Tumbuh dalam Perbanyakan Tanaman melalui Kultur Jaringan. Jurnal AgroBiogen 7 (1).

Pancaningtyas, S. dan C. Ismayadi. 2001. Sterilisasi Ulang pada Perbanyakan Somatic Embryogenesis Kakao (Theobromo cacao L.) untuk PenyelamatanEmbrioTerkontaminasi. Pelita Perkebunan 27(1).

Priadi D, Fitriani H, Sudarmonowati E. 2008. Pertumbuhan in vitro Tunas Ubi Kayu (Manihot esculenta Crantz) pada Berbagai Bahan Pemadat Alternatif Pengganti Agar. Biodiversitas. Vol. 9 No. 1 Hal. 9-12.

Rahmat R. 2004. Teтu-Temuan Apotik Hidup Di Pekarangan. Kanisius : Yogyakarta.

Samson A.R dan Reenen Hoekstra ES van. 1988. Introduction to Food Borne Fungi. Centralbureau Voor
Schimmelcultures. Baarn. Delpt.

Sandra, E.2002. Membuat Anggrek Rajin Berbunga. Jakarta: Agro Media Pustaka. Jakarta.

Savitri, S.D.N. 2006. Isolasi dan Karakteristik Bakteri Halotoleran Pada Peda Ikan Kembung (Rastrellinger sp.). Skripsi. IPB, Bogor.

Shofiyani, A., O.D. Hajoeningtijas. 2010. Pengaruh Sterilan Dan Waktu Perendaman Pada Eksplan Daun Kencur ( Kaemferia galanga L) Untuk Meningkatkan Keberhasilan Kultur Kalus. AGRITECH, Vol. XII No. 1 Juni $2010: 11-29$

Suratman, Pitoyo, A. Mulyani, S. 2013. Keefektifan Penggunaan Bahan Sterilisasi Dalam pengendalian Kontaminasi Eksplan Pada Perbanyakan tanaman Sirsak (Annona Muricata L.) Secara In Vitro. Jurnal Jurusan Biologi FMIPA UNS Surakarta

Syamsuhidayat, S.S. dan Johny, R.H,. 1991. Inventaris Tanaman Obat Indonesia (1).Jakarta: Bakti Husada. hal 596-7

Tulainy, I. 2016. pengaruh auksin $(2,4 \mathrm{~d})$ dan air kelapa terhadap induksi kalus pada rimpang kencur (Kaempferia galanga $L$ ). Skripsi. UMP.

Watanabe, T, 2002. Pictorial Atlas of Soil and Seed Fungi. CRC Press, New York Wolf, J.B. 2007. Tissue Culture Methods. Departement of Biological Sciences, University of Maryland. Baltimore Country 1000 Hilltop Circle Baltimore Md 21250.

Wudianto, R. 2002. Petunjuk Penggunan Pestisida. Jakarta: Penebar Swadaya. 